\title{
Nanoparticles containing aqueous seed extract of Syzygium cumini (npasc) protect against oxidized LDL particles in vitro
}

\author{
Paula Eliete Rodrigues Bitencourt ${ }^{*}$ Luana Mota Ferreira, Carolina dos Santos Stein, Manuela Sangoi, Laura Denardi, \\ Raphaela Maleski Borges, Letícia Cruz, Rafael Noal Moresco, Sydney Alvez Hartz, Maria Beatriz Moretto
}

From 20th Brazilian Diabetes Society Congress

Porto Alegre, Brazil. 11-18 November 2015

\section{Background}

Diabetes mellitus (DM) is a heterogeneous group of metabolic disorders which affects over $10 \%$ of the world population. The diabetes-induced oxidized low-density lipoprotein (ox-LDL) can affect several components of the atherogenic process [1]. Nanodosage forms can provide advantages for herbal drugs, including increase of therapeutic index, improvement of stability and controlled delivery.

\section{Objectives}

To evaluate the effect of NPASc and the major constituents of the extract (gallic acid, GA; chlorogenic acid, $\mathrm{CA}$; rutin, $\mathrm{R}$ ) on the levels of lipoperoxidation of ox-LDL particles by AAPH, in vitro.

\section{Materials and methods}

LDL was isolated from human serum $(n=6)$ [2]. LDL isolated samples were incubated with/without NPASc, GA, $\mathrm{CA}$ and $\mathrm{R}(0.1 ; 0.25 ; 0.5$ and $1 \mathrm{mg} / \mathrm{mL})$ at $37^{\circ} \mathrm{C}$ for $30 \mathrm{~min}$. At the end of incubation, the samples were oxidized in the presence of $20 \mu \mathrm{M} \mathrm{AAPH}$, for $4 \mathrm{~h}$ at $37^{\circ} \mathrm{C}$. The oxidation was estimated by measuring the thiobarbituric acid reactive substances (TBARS, nmol MDA/mg of protein) [3]. $\mathrm{N}^{\circ}$ of the Ethic Committee (0049.0.243.000-08).

\section{Results}

Our results demonstrate that NPASc and the compounds protected LDL particles from the oxidation by AAPH, demonstrating that the known antioxidant activity of S. cumini was maintained. GA and CA showed a

* Correspondence: paulinha.farma.bitencourt@hotmail.com Universidade Federal De Santa Maria, Santa Maria, Brazil

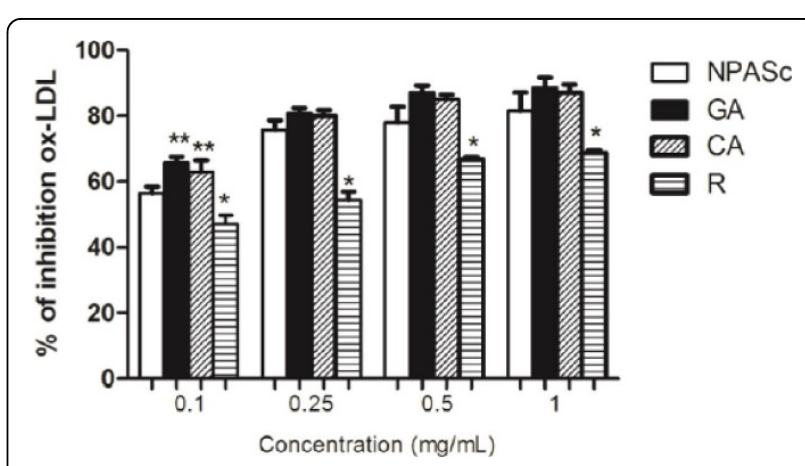

Figure 1 NPASc, GA, CA and R activities against ox-LDL in the AAPH assay. Data are mean \pm S.E.M $(n=6)$. Differences among compounds within the same concentration: ${ }^{*} p<0.05$ compared to all; **p $<0.05$ compared to NPASc

significant antioxidant activity, although less than that observed with NPASc; R had a lower effect when compared to other groups. This result confirms the possible antiatherogenic potential of the extract.

\section{Conclusion}

NPASc could act to lower the ox-LDL presence in the circulation, reducing the number of proatherogenic potentials thus avoiding the formation of atherosclerotic lesions.

\section{Published: 11 November 2015}

\section{References}

1. Sociedade Brasileira de Diabetes: Diretrizes da Sociedade Brasileira de Diabetes. 2014, Available at http://diabetes.org.br. Accessed 29 April 2015. 2. Ahotupa $M$, et al: Baseline diene conjugation in LDL lipids as a direct measure of in vivo LDL oxidation. Clin Biochem 1998, 31:257-261. 
3. Okawa $\mathrm{H}$, et al: Assay for lipid peroxides in animal tissues by thiobarbituric acid reaction. Ann Biochem 1979, 95:351-358.

doi:10.1186/1758-5996-7-S1-A1

Cite this article as: Bitencourt et al: Nanoparticles containing aqueous seed extract of Syzygium cumini (npasc) protect against oxidized LDL particles in vitro. Diabetology \& Metabolic Syndrome 2015 7(Suppl 1):A1.

Submit your next manuscript to BioMed Central and take full advantage of:

- Convenient online submission

- Thorough peer review

- No space constraints or color figure charges

- Immediate publication on acceptance

- Inclusion in PubMed, CAS, Scopus and Google Scholar

- Research which is freely available for redistribution

Submit your manuscript at www.biomedcentral.com/submit
Ciomed Central 